\title{
KONSEP DASAR PEMBINAAN KESADARAN BERAGAMA DALAM DUNIA PENDIDIKAN ANAK
}

\author{
Khanif Maksum
}

(Dosen PGMI STIA Alma Ata Yogyakarta)

\begin{abstract}
Religious awarness in a person is an important factor in determining peace and happiness of buman life. Because it will guide him endure his/her life solidly and strongly foundation in the world. In early childhood, religion awarness should be emphasized properly and sustainably, in order to be internalized in next thier life. Therefore, in young generation education, moral and religious life required consistent and serious attention.

Improving of religious life for children, can be a positive influence on the life of children, both in culture, social and religious segments. Children can keep themselves from a moral action among the students and young generation and to avoid from current of a negative culture which is disseminate through multiple media, eg. news paper, readings, pictures, broadcasts and performances.
\end{abstract}

Keywords: Religious awareness, life of children

\section{A. PENDAHULUAN}

Timbulnya jiwa keagamaan anak pada masa prasekolah dan masa sekolah biasanya ditandai dengan munculnya berbagai macam pertanyaan yang ditujukan kepada orangtua dan gurunya, baik mengenai keadaan yang berhubungan dengan dirinya sendiri, seperti tentang masalah asal usul dirinya, pertanyaan tentang masalah Tuhan dan berbagai pertanyaan yang terkadang susah dijawab oleh para pendidiknya.

Potensi keagamaan terhadap seorang anak telah ada sejak dalam kandungan sebagaimana firman Allah SWT: Artinya, dan (ingatlah), ketika Tuhanmu mengeluarkan keturunan anak-anak Adam dari sulbi mereka dan Allah mengambil kesaksian terhadap mereka (seraya berfirman): Engkau Tuhan kami, kami jadi saksi (QS. Al-Araaf /7; 172). 
Dari ayat tersebut jelaslah bahwa dalam tabiat manusia terdapat kesiapan alamiah untuk mengenal Allah dan mengesakan- Nya.

Pengakuan terhadap kedudukan Allah sebagai Tuhan tertanam kuat dalam fitrahnya, tinggal bagaimana pengembangan serta pemeliharaan potensi (perasaan religius) yang ada pada anak tersebut, maka disinilah peran para pendidik dalam mengembangkan keagamaan anak. Dalam kehidupan manusia memiliki potensi beragama bahkan potensi tersebut sudah dianggap sebagai kebutuhan spiritual manusia.

\section{B. PEMBAHASAN}

Agama memerlukan pengembangan melalui bimbingan dan pemeliharaaan yang cukup berat lebih-lebih pada masa usia dini. Tandatanda keagamaan pada diri anak tumbuh dan terjalin secara integral dengan perkembangan fungsi-fungsi kejiwaan pada diri anak. Belum terlihatnya tindakan keagamaan pada diri anak karena beberapa fungsi kejiwaan yang belum sempurna. Namun demikian pengalamanpengalaman yang diterima oleh anak dari lingkungan akan membentuk rasa keagamaan pada diri anak. Oleh karena itu, perlu usaha bimbingan dan latihan dari pendidik seiring dengan perkembangan anak. Perkembangan jiwa agama pada anak semakin berkembang bila diiringai dengan kasih sayang dari orang-orang yang ada disekelilingnya.

Perkembangan jiwa agama pada anak dimulai sejak lahir dan akan terus berkembang dimulai dengan anak bisa bicara dan menyebut nama Tuhan sampai akhirnya ia melihat orang disekitarnya mengerjakan ibadah sebagai perintah Allah yang akhirnya jiwa agama pada anak akan terus berkembang seiring dengan perilaku orang tua yang agamis dan mengarahkan anaknya pada pendidikan yang benar.

\section{DASAR - DASAR PENDIDIKAN AGAMA ANAK}

Ketika seorang anak pertama kali lahir ke dunia dan melihat apa yang ada di dalam rumah dan sekelilingnya, tergambar dalam benaknya sosok awal dari sebuah gambaran kehidupan. Bagaimana awalnya dia harus bisa melangkah dalam hidupnya didunia ini. Jiwanya yang masih suci dan bersih akan menerima segala bentuk apa saja yang datang mempengaruhinya. Maka sang anak akan dibentuk oleh setiap pengaruh yang datang dalam dirinya. Dalam hal ini Imam Ghazali mengatakan: "Bayi itu merupakan amanat bagi kedua orang tuanya, 
batinya suci dan bersib. Jika dibiasakan dan diajarkan kebaikan, ia akan tumbub dengan kebiasaan, pengajaran, dan berbahagia di dunia dan di akbirat."

Dengan demikaian orang tua harus berusaha semaksimal mungkin agar anak mendapatkan pendidikan agama yang baik dan terbiasa melaksanakannya. Berbicara tentang terbiasa melaksanakan berarti menyangkut metode keteladanan, metode keteladanan dalam pembiasaan merupakan suatu metode yang digunakan untuk merealisasikan tujuan pendidikan dengan memberi contoh keteladanan yang baik kepada anak agar mereka dapat berkembang baik fisik maupun mental dan memiliki akhlak yang baik dan benar. Keteladanan memberikan kontribusi yang sangat besar dalam pendidikan ibadah, aklak, kesenian dan lain-lain. ${ }^{2}$ Oleh karena itu yang perlu kita ketahui adalah bentuk-bentuk pelaksanaan ajaran islam atau dasar - dasar pendidikan agama bagi anak yaitu:

\section{Pembinaan Aqidah pada Anak}

Aqidah secara bahasa berarti ikatan, secara terminologi berarti landasan yang mengikat yaitu keimanan. Aqidah juga sebagai ketentuan dasar mengenai keimanan seorang muslim, landasan dari segala prilakunya, bahkan aqidah sebenarnya merupakan landasan bagi ketentuan syariah yang merupakan pedoman bagi seseorang berprilaku di muka bumi. ${ }^{3}$

Aqidah memiliki enam aspek yaitu: keimanan pada Allah, pada para malaikat-Nya, iman kepada para Rasul utusan-Nya, pada hari akhir, dan iman kepada ketentuan yang telah dikehendaki-Nya. Apakah ini takdir baik atau takdir buruk. dan seluruh aspek ini merupakan hal yang ghaib kita tidak mampu menangkapnya dengan panca indra kita. ${ }^{4}$

1. Abdullah Nashih Ulwan, Tarbiyah Al-Aulad fi Al-Islam, diterjemahkan oleh Khalilullah amhad Masykur Hakim dengan judul Pendidikan Anak menurut Islam Kaedahkaedah Dasar, (Cet. I; Bandung: Remaja Rosdakarya, 1992), hlm.160

2. Hery Noer Ali, Ilmu Pendidikan Islam, (Cet. II; Jakarta: Logos, 1999), hlm.185

3. Zakiah Daradjat, Dasar-dasar Agama Islam, (Cet.VIII; Jakarta: Bulan Bintang, 1993), hlm.317

4. Muhammad Nur Abdul Hafizh, Mendidik Anak Bersama Rasulullah, (Cet.II; Kairo: Al-Bayan,1988), hlm. 109 
Seperti yang telah dijelaskan di atas maka kita akan menemukan lima pola dasar pembinaan aqidah anak seperti : Membacakan kalimat tauhid pada Anak, menanamkan kecintaan mereka pada Allah, pada Rasulullah Muhammad SAW, mengajarkan $\mathrm{Al}$-qur'an dan menanamkan nilai perjuangan rasul serta pengorbanan beliau pada mereka.

Imam Al- Gazali menjelaskan secara khusus bagaimana menanamkan keimanan pada anak. Belaiau berkata, "Langkah pertama yang bisa diberikan kepada mereka dalam menanamkan keimanan adalah dengan memberikan hafalan. Sebab proses pemahaman harus diawali dengan hafalan terlebih dahulu. Ketika anak hafal akan sesuatu kemudian memahaminya, akan tumbuh dalam dirinya sebuah keyakinan dan akhirnya anak akan membenarkan apa yang telah dia yakini sebelumnya. Inilah proses pembenaran dalam sebuah keimanan yang dialami anak pada umumnya. ${ }^{5}$

Dalam proses penanaman aqidah ini, kita dapat perlu mengajarkan pada anak bagaimana cara mereka berbicara atau menjelaskan tentang pemahaman mereka terhadap aqidah. Tapi cukuplah bagi mereka untuk menyibukkan diri dengan banyak membaca Al-Qur'an, mempelajari tafsirnya, juga hadis-hadis Rasulullah SAW serta sibukkan mereka dengan amalan - amalan keseharian dalam ibadah ritual. Dengan demikian secara tidak langsung akan timbul keyakinan dengan sendirinya dalam diri anak ketika mereka tengah membaca $\mathrm{Al}$-qur'an dan hadis.

\section{Pembinaan Ibadah pada Anak}

Pembinaan anak dalam beribadah dianggap sebagai penyempurna dari pembinaan aqidah karena nilai ibadah yang didapat oleh anak akan dapat menambah keyakinan akan kebenaran ajarannya atau dalam istilah lain, semakin tinggi nilai ibadah yang ia miliki, akan semakin tinggi pula keimanannya. Maka bentuk ibadah yang dilakukan anak bisa dikatakan sebagai cerminan atau bukti nyata dari aqidahnya.

Apabila kita amati lebih dalam lagi arti ibadah dimata manusia, akan kita temukan bahwa ternyata bentuk pengabdian ini semata-mata merupakan fitra setiap manusia yang dihadirkan Allah. Oleh karena 
itu kewajiban orang tua atau pendidik adalah mengarahkan kembali fitra pengabdian anak pada sang khalik yang telah tertanam sejak ditiupkannya ruh oleh Allah kepadanya ketika dia masih berada di dalam kandungan.

Masa kecil anak bukanlah masa pembebanan atau pemberian kewajiban, tapi merupakan masa persiapan, latihan dan pembiasaan. Sehingga ketika mereka sudah memasuki masa dewasa yaitu pada saat mereka mendapatkan kewajiban dalam beribadah, segala jenis ibadah yang Allah wajibkan dapat mereka lakukan dengan penuh kesadaran dan keikhlasan. Karena sebelumnya mereka sudah terbiasa melakukan ibadah tersebut.

Bentuk pengabdian seorang hamba terhadap Tuhannya atau dalam istilah khusus yaitu ibadah memiliki pengaruh yang sangat menakjubkan dalam diri anak. Pada saat anak melakukan salah satu ibadah itu, secara tidak disadari ada dorongan kekuatan yang membuat dia merasa tenang dan tentram.

Pembinaan dalam beribadah bagi anak ini terbagi dalam 4 dasar pembinaan yaitu:

a. Pembinaan Shalat

Pembinaan shalat ini bertahap mulai dari perintah melaksanakan shalat, anak mulai dikenalkan adanya kewajiban dalam melaksanakan shalat baik itu syarat sah shalat maupun rukun-rukun shalat serta larangan-larangannya, membiasakan anak menghadiri shalat jum'at, membawa anak ikut kemasjid dan mengikat anak dengan masjid.

Dengan adanya upaya seperti diatas maka semakin besar harapan masyarakat pada zaman ini untuk dapat melihat lahirnya sebuah genersi baru yang cemerlang, generasi yang didalamnya terdapat orang-orang yang telah mengabdikan diri sepenuhnya untuk berjalan diatas kebenaran.

b. Pembinaan Ibadah Puasa

Puasa merupakan ibadah ritual yang berhubungan erat dengan proses peningkatan ruh dan jasad. Didalam ibadah ini anak diajark untuk mengenal semakin dalam makna sebenarnya dari bentuk keihlasan dihadapan Allah SWT karena puasa bukan hanya mengajarkan anak untuk menahan diri dari haus dan lapar saja tapi juga dilatih untuk selalu bersikap sabar dan tabah. 
c. Pembinaan mengenai Ibadah Haji

Ibadah haji sama dengan rukun ibadah yang lainnya, tidak diwajibkan sepenuhnya pada anak. Melainkan sebagai sarana untuk melatih diri anak agar terbiasa dalam melaksanakan bentuk ibadah yang memerlukan ketabahan fisik yang kuat.

Sebagaimana kita ketahui pula bahwa haji merupakan bentuk ibadah yang penuh dengan berbagai macam kesulitan dan kepayahan dalam melaksanakan rangkaian ibadah tersebut. Maka dengan dilaksanakannya ibadah tersebut semenjak usia anak masih kecil, diharapkan pada saat mencapai dewasa nanti, dia akan mulai terbiasa dan tidak lagi dianggap sebagai bentuk ibadah yang berat baginya. ${ }^{6}$

d. Pembinaan Ibadah Zakat

Salah satu bentuk pembinaan ibadah lainnya adalah mengenalkan anak pada rukun ibadah yaitu mengeluarkan Zakat fitra yang merupakan bentuk kewajiban setiap muslim, tidak memandang umur atau jenis kelamin. Dengan mengeluarkan zakat ini, anak dikenalkan pada bentuk penyucian harta dan diri. Maka anak pun akan belajar mengenal arti tolong menolong yang merupakan kewajiban setiap manusia. Karena harta yang dikeluarkan akan disalurkan kepada mereka yang membutuhkan.

3. Pembinaan Akhlak pada Anak

Akhlak secara bahasa berasal dari kata khalaqa yang kata asalnya kbuluqun yang berarti: perangai, adat, atau khalqun yang berarti kejadian, buatan, ciptaan. Jadi secara atimologi akhlak itu berarti perangai, adat, tabiat, atau system prilaku yang dibuat. ${ }^{7}$

Akhlak secara kebiasaan bisa baik ataupun buruk. Tergantung kepada tata nilai yang dipakai sebagai landasannya. Meskipun secara sosiologis di Indonesia kata akhlak sudah mengandung konotasi baik, jadi orang yang berakhlak berarti orang yang berakhlak baik.

Adapun pembinaan Akhlak kepada anak, yaitu:

a. Pembinaan Budi Pekerti dan Sopan Santun.

Tirmizi meriwayatkan dari Sa'id bin 'Ash, Rasulullah SAW. Bersabda "Tidak ada pemberian seorang bapak pada anaknya yang lebih baik

6. Ibid., hlm. 165

7. Zakiah Daradjat, Op. Cit., hlm. 253 
dari budi pekerti yang lubur". Oleh karena itulah Ali Al-Madani berkata, "Mewariskan budi pekerti yang luhur kepada anak adalah lebih baik dari pada mewariskan harta kepadanya, karena budi pekerti yang luhur dapat memberikan harta dan kemuliaan dan rasa cinta terhadap para saudara. Lebih jelasnya, budi pekerti yang luhur dapat memberikan kenikmatan dunia dan akhirat. ${ }^{8}$ Adapun adab dan budi pekerti yang diajarkan oleh Rasulullah antara lain adalah: (a). Sopan santun terhadap orang tua, baik adab berbicara dengan orang tua, maupun adab memandang orang tua. (b). Sopan santun terhadap ulama. (c). Etika menghormati orang yang lebih tua. (d). Etika Bersaudara. (e). Etika Bertetangga. (f). Etika ketika makan. Dan sebaganya.

b. Pembinaan Bersikap Jujur

Bersikap jujur merupakan dasar pembinaan akhlak yang sangat penting dalam ajaran islam ini. Sikap seperti ini memerlukan perjuangan yang tidak ringan, karena banyaknya godaan dari lingkungan sekitar yang membuat untuk tidak bersikap jujur. Oleh karena itu Rasulullah SAW begitu memperhatikan pendidikan kejujuran ini dengan membinanya sejak usia anak masih sangat kecil. ${ }^{9}$

c. Pembinaan menjaga Rahasia

Rasulullah SAW begitu perhjatian penuh dalam membentuk anak yang bisa menjaga rahasia. Karena sikap seperti ini merupakan perwujudan dari keteguhan anak dalam membela kebenaran. Anak akan mampu hidup ditengah masyarakat dengan penuh percaya diri dan masyarakatpun akan mempercayaianya. ${ }^{10}$

d. Pembinaan menjaga kepercayaan

Al-Amanah atau kepercayaan merupakan sifat dasar Rasulullah SAW yang telah beliau miliki sejak usia kecil hingga masa kerasulannya. Sampai kaum Musyrik menjuluki beliau dengan sebutan "Orang jujur dan dipercaya" atau dalam istilah lain "Al-Shadiq AlAmin. Contoh teladan ini seperti ini yang mesti ditiru oleh setiap generasi Muslim pada masa sekarang ini. Karena dasar kepercayaan

\footnotetext{
8. Muhammad Nur Abdul Hafizh, Op. Cit., hlm. 179

9. Ibid., hlm. 165

10. Zakiah Daradjat, Op. Cit., hlm. 253
} 
inilah yang menjadi salah satu kriteria suksesnya dakwah islam dimanapun berada. ${ }^{11}$

e. Pembinaan menjauhi sifat dengki.

Bersihnya hati anak dari rasa iri atau dengki merupakan salah satu bentuk pembinaan yang menjadi sasaran utama orang tua terhadap anaknya. Karena dengan hilangnya sifat dengki yang ada dalam jiwanya, anak akan memiliki pribadi yang luhur dan selalu mencintai kebaikan ditengah-tengah masyarakat dan selalu tegar dari gangguan penyakit hati orang-orang disekitarnya. Demikian Rasulullah SAW selalu mengajarkan anak-anak para sahabatnya untuk menjauhi sifat dengki dan bersikap lapang dada terhadap orang-orang yang berniat buruk padanya, serta mengosongkan hatinya dari gangguan setan.

\section{URGENSI PEMBINAAN KEHIDUPAN BERAGAMA BAGI ANAK}

Dalam kehidupan sehari-hari, sangat banyak sekali kebiasaan yang berlangsung otomatis dalam bertingkah laku. Oleh karena itu pembinaan kehidupan beragama melalui proses pendidikan yang baik akan sangat berpengaruh dari genersi ke generasi sehingga membudaya dalam kehidupan. Pembinaan kehidupan beragama sangat penting bagi anak, sebagai mana yang dikatakan oleh Zakiah Darajat bahwa: Pembinaan moral dan agama bagi generasi muda tidak dapat dipisahkan dari keyakinan beragama. Karena nilai-nilai moral yang tegas, pasti, dan tetap, tidak berubah karena keadaan, tempat, dan waktu atau nilai yang bersumber kepada agama. Oleh karena itu dalam pembinaan generasi muda, kehidupan moral dan agama harus sejalan dan mendapat perhatian yang serius. ${ }^{12}$

\section{E. PENGARUH PEMBINAAN KEHIDUPAN BERAGAMA BAGI ANAK.}

Dengan adanya pembinaan kehidupan beragama bagi anak, dapat memberikan pengaruh positif terhadap kehidupan anak. Baik

11. Muhammad Nur Abdul Hafizh, Op. Cit., hlm. 179

12. Zakiah Darajat, Pendidikan Agama Islam Dalam Pembinaan Mental, (Cet. IV; Jakarta: PT. Bulan Bintang, 1982), hlm.39 
dari segi budaya, social dan religi. Adapun pengaruh pembinaan kehidupan beragama bagi anak antara lain:

1. Pengaruh dari segi sosial :

Seperti yang dikemukaan oleh Muh. Nur Abdul Hanizh bahwa Pembinaan membuat anak bisa bersikap benar dalam pergaulannya dengan masyarakat disekitarnya, baik bergaul dengan anak seusianya, maupun dalam adab kesopanan terhadap orang yang lebih dewasa. ${ }^{13}$

Anak dapat berkelakuan yang sesuai dengan ukuran - ukuran (nilai-nilai) masyarakat, yang timbul dari hatinya sendiri, bukan paksaan dari luar, yang disertai pula oleh rasa tanggung jawab atas kelakuan (tindakan) tersebut. Tindakan itu haruslah mendahulukan kepentingan umum dari pada kepentingan atau keinginan pribadi. ${ }^{14}$

Menurut Ibn Miskawaih (abad ke-X M) bahwa segala perbuatan anak, baik itu saling tolong menolong dan lain sebagainya adalah sesuatu keinginan yang lahir dengan mudah dari jiwa anak dengan tulus tanpa memerlikan pertimbangan dan pemikiran lagi. Inilah Pengaruh pembinaan kehidupan beragama bagi anak terhadap kehidupan sosialnya. ${ }^{15}$

2. Pengaruh dari segi Religi:

Dengan adanya pembinaan kehidupan beragama pada anak, maka: (a). Anak yakin dan percaya terhadap adanya Tuhan (Allah) serta Kekuatan Tuhan yang dapat melindungi dan memberi pertolongan terhadap ummatnya. (b). Anak mampu melakukan hubungan yang sebaik-baiknya dengan Tuhan, guna mencapai kesejahteraan hidup didunia dan di akhirat. (c). Anak dapat mencintai dan melaksanakan perintah serta menjauhi larangan tuhan dengan jalan beribadah yang setulus-tulusnya.(d). Anak yakin dan percaya adanya hal-hal yang dianggap suci dan sakral, seperti: kitab suci, tempat ibadah, dan sebagainya. ${ }^{16}$

3. Pengaruh dari segi Budaya:

13. Ibid., hlm. 169

14. Zakiah Daradjat, Peran Agama dalam Kesehatan Mental, (Cet.IV; Jakarta: Gunung Agung, 1978), hlm.63

15 Departemen Agama, Op.cit., hlm.204

16. Ibid., hlm. 165 
Dengan pembinaan agama tersebut anak bisa menjaga diri dari kerusakan moral dikalangan pelajar dan generasi muda serta terhindar dari derasnya arus budaya yang negatif. Yang banyak di salurkan melalui beberapa media, baik itu melalui bacaan-bacaan, lukisanlukisan, siaran-siaran, pertunjukan dan lain sebagainya. ${ }^{17}$

Dengan demikian pembinaan Etika, moral, kaidah agama yang diberikan pada anak memiliki banyak peran dalam membimbing anak menuju terbentuknya masyarakat yang sejahtera lahir maupun batin, termasuk dalam menciptakan persatuan dan kesatuan bangsa. 


\section{F. KESIMPULAN}

Pembinaan moral dan agama bagi generasi muda yakni anak tidak dapat dipisahkan dari keyakinan beragama. Karena nilai-nilai moral yang tegas, pasti, dan tetap, tidak berubah karena keadaan, tempat, dan waktu atau nilai yang bersumber kepada agama. Oleh karena itu dalam pembinaan generasi muda, kehidupan moral dan agama harus sejalan dan mendapat perhatian yang serius

Dengan adanya pembinaan kehidupan beragama bagi anak, dapat memberikan pengaruh positif terhadap kehidupan anak. Baik dari segi budaya, social dan religi. Anak bisa menjaga diri dari kerusakan moral dikalangan pelajar dan generasi muda serta terhindar dari derasnya arus budaya yang negatif. Yang banyak di salurkan melalui beberapa media, baik melalui bacaan-bacaan, lukisan-lukisan, siaran-siaran, pertunjukan dan lain sebagainya 


\section{DAFTAR PUSTAKA}

Abdullah Nashih Ulwan, Tarbiyah Al-Aulad fi Al-Islam, diterjemahkan oleh Khalilullah amhad Masykur Hakim denganjudul Pendidikan Anak menurut Islam Kaedah-kaedah Dasar, Cet. I; Bandung: Remaja Rosdakarya, 1992

Departemen Agama, Alqur'an dan Terjemahnya, 2002.

Hery Noer Ali, Ilmu Pendidikan Islam, Cet. II; Jakarta: Logos, 1999

Muhammad Nur Abdul Hafizh, Mendidik Anak Bersama Rasulullah, Cet.II; Kairo: Al-Bayan,1988

Zakiah Daradjat, Dasar-dasar Agama Islam, Cet.VIII; Jakarta: Bulan Bintang, 1993

.....,Peran Agama dalam Kesehatan Mental, Cet.IV; Jakarta: Gunung Agung, 1978

.....,Pendidikan Agama Islam Dalam Pembinaan Mental, Cet. IV; Jakarta: PT. Bulan Bintang, 1982 